\title{
Status, distribution and use of threatened tree species in the walnut-fruit forests of Kyrgyzstan
}

\author{
Almaz Orozumbekov ${ }^{\mathrm{a}}$, Elena Cantarello ${ }^{\mathrm{b} 1}$ and Adrian C. Newton ${ }^{\mathrm{b} *}$ \\ ${ }^{a}$ Eurasian Faculty of Innovative Technology, Kyrgyz National Agrarian University, 68 Mederov \\ Street, Bishkek 720005, Kyrgyzstan; ${ }^{b}$ Faculty of Science and Technology, Bournemouth University, \\ Talbot Campus, Fern Barrow, Poole Bh12 5BB, UK
}

\begin{abstract}
Information is lacking on the status of threatened tree species in Central Asia. This paper aims to provide preliminary information for 10 fruit and nut tree species of Kyrgyzstan. A field survey was conducted throughout the range of walnut-fruit forests in this country, supported by a socio-economic survey. Results indicated that species differed markedly in abundance. Whereas Malus sieversii was found in all locations, four species (Crataegus pontica, Pistacia vera, Pyrus korshinskyi and Sorbus persica) were only found in a minority $(\leq 30 \%)$ of sites. Four species showed evidence of a bimodal distribution of stem diameters, which could be attributed to fuelwood harvesting, as indicated by the socio-economic survey. A majority of respondents reported a decline in the available grazing resource, a decline in the availability of harvested fruits and an increase in time required to collect fuelwood over the past decade. These results suggest that unsustainable land-use practices may be impacting negatively on populations of threatened fruit tree species. These results highlight the need to regulate local forest use to ensure that threatened fruit and nut tree species are effectively conserved, and the need for targeted actions to conserve the most threatened species, such as $P$. korshinskyi.
\end{abstract}

Keywords: anthropogenic disturbance; Kyrgyzstan; Malus spp; non-timber forest product; Red List; sustainable use; threatened species; walnut-fruit forests

\section{Introduction}

Globally, forests are believed to contain more than $80 \%$ of terrestrial biodiversity (FAO 2012) and have consequently been the focus of particular conservation concern in recent years (Newton 2007a). In many areas, native forests are being subjected to intensive human disturbance, through activities such as cutting, burning and browsing by livestock. Such processes can result in forest clearance, degradation and fragmentation, and consequent loss of biodiversity (Newton 2007b; Newton et al. 2009). An important element of this biodiversity is the tree species that form a key functional and structural component of forest communities. The conservation of tree species has been received relatively little attention in the context of global conservation efforts, despite the fact that many tree species appear to be threatened with extinction. In an overview of 10 recent

The senior author of this publication, Dr Almaz Orozumbekov, sadly passed away while this manuscript was in review. We dedicate this publication to his memory; having studied the walnutfruit forests of Kyrgyzstan for many years, he had a long-held ambition to see his results published in an international journal, and was very much looking forward to seeing this paper appear in print. His premature death represents a great loss to the walnut-fruit forests in Kyrgyzstan, and to the forest research community in Central Asia.

*Corresponding author. Email: anewton@ bournemouth.ac.uk 
assessments of the conservation status of tree species, in which a total of around 2500 taxa were evaluated, a mean of $42 \%$ were classified as threatened (Newton \& Oldfield 2008).

This raises the question of how tree species can be effectively conserved. Many rural communities depend on exploitation of tree species to support their livelihoods, and therefore there is a need to integrate conservation with human use. The issue of how conservation and use of species can be successfully combined has been the focus of an ongoing debate (Milner-Gulland \& Mace 1998; Hutton \& Leader-Williams 2003). In the context of tree species, Newton (2008) suggested that an adaptive management approach is required, in which human activities are modified in response to information describing the impact of such activities. For this to be effective, those people using the species should be involved in monitoring the impacts of use, as part of a participatory management approach. For such an approach to be effective, information is required both on the current status of tree species and the potential impacts of human use.

This paper aims to provide such information for threatened tree species of the walnut-fruit forests in the Tien Shan region of Kyrgyzstan. These are mixed forests dominated by walnut (Juglans regia), which are widely recognised to be a global conservation priority (Myers et al. 2000; Olson et al. 2001), and have been exploited in an intensive manner, particularly since Kyrgyzstan become independent in 1991 (Schmidt 2005, 2012). Walnut is distributed from China, Nepal and India in the east, across Central Asia, and westwards to Iran, Azerbaijan and Turkey (McGranahan \& Leslie 1991; Hemery \& Popov 1998). Although it is thought to be native throughout this range, its natural distribution is difficult to determine with precision because of the potential role of distribution by humans in historical times. The term 'walnut-fruit forests' is conventionally used to refer to all mixed forest and shrub communities whose species composition includes walnut and any of the wild fruit tree species of the region (Epple 2001). In Kyrgyzstan, fruit trees commonly associated with walnut whose fruits are used for human consumption include Prunus spp., Malus spp., Pyrus spp., Ribes spp., Crataegus spp. and Berberis spp. (Epple 2001). As for walnut, the natural distribution of these fruit tree species is imperfectly known. Juniper and Mabberley (2006) conclude that Malus pumila (including the natural populations formerly called Malus sieversii) is native to the mountains of Inner and Central Asia, principally the Tien Shan region. The natural distribution of this species has been obscured by its dispersal by humans along the Silk Road in antiquity, a suggestion supported by genetic analysis (Harris et al. 2002; Juniper \& Mabberley 2006). Conceivably, other fruit and nut trees of the region could have similarly been distributed by people over a timescale of millennia. This suggests that these forests may have played a significant role in human history and culture, being the source of domesticated tree crops that are now widely cultivated (Juniper et al. 1998; Deakin 2007). In addition, these findings suggest that walnut-fruit forests are of exceptional importance as a genetic resource (Hemery \& Popov 1998; Harris et al. 2002; Juniper \& Mabberley 2006).

The most extensive areas of walnut-fruit forests that remain are those situated in Kyrgyzstan (Epple 2001). Here, the walnut-fruit forests are located on the western and south-western slopes of the Fergana and Chatkal mountain ridges in the Jalal-Abad region in the south of the country (Figure 1), where the climate is continental. The most sizeable tracts are located in Arslanbob-Kurgat and Khozha-Aty (Hemery \& Popov 1998); these are also the richest in species (Epple 2001). In both the Fergana and Chatkal mountain ranges, walnut-fruit forests primarily occur from 800 to 2100 m a.s.l. (Hemery \& Popov 1998). The original extent of the walnut-fruit forests in Kyrgyzstan is difficult to estimate with precision. According to a natural resource survey undertaken between 1966 and 1968 , the total area of the walnut-fruit forests was 632,500 ha, including 230,700 ha of natural forests (Musuraliev 1998). Estimates of the current area vary; Venglovsky (1998) suggests 


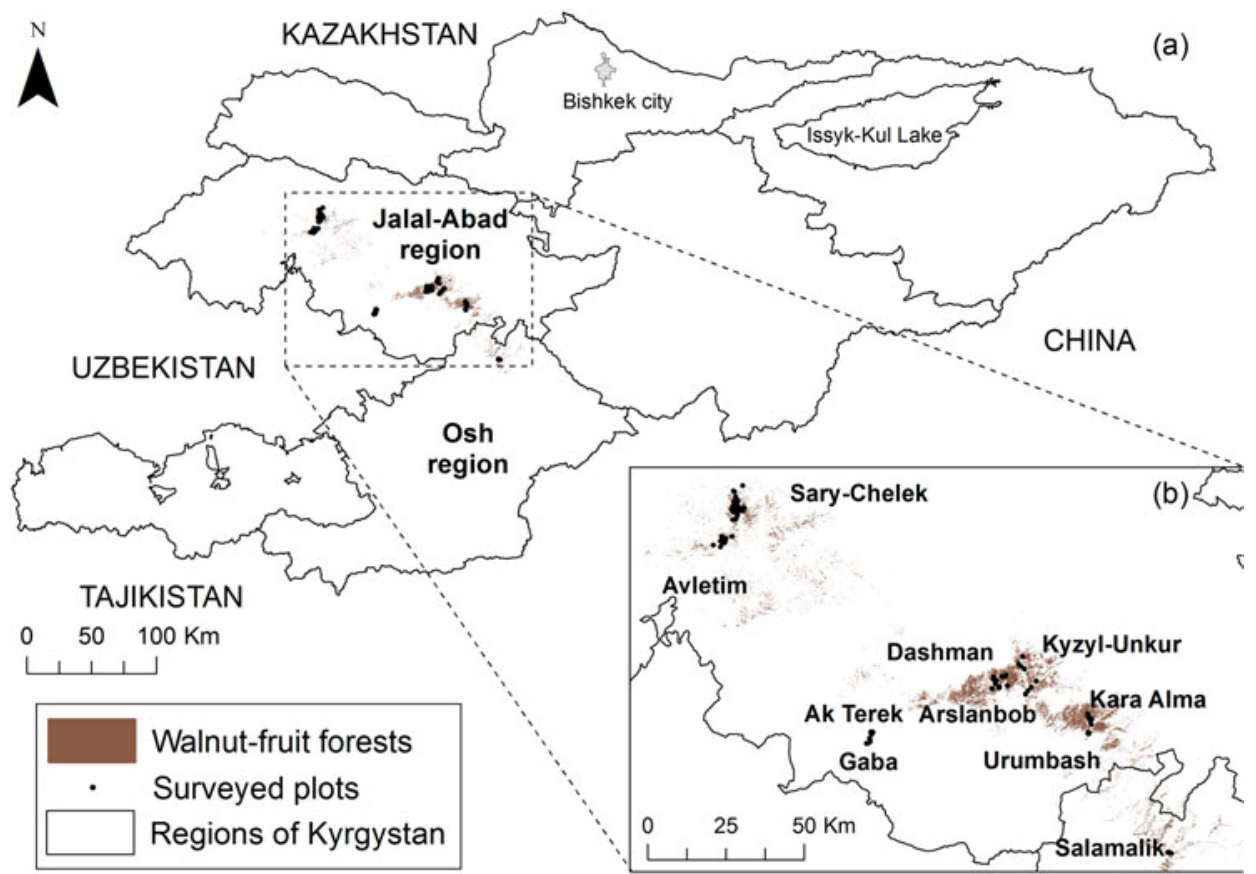

Figure 1. (a) Map showing the extent of the walnut-fruit forests within Kyrgyzstan; this was derived from the forest map produced by the National Academy of Sciences of the Kyrgyz Republic (2009). (b) Close-up of the sample plots locations within the walnut-fruits forests shown in insert (a).

a walnut-fruit forest area of 92,700 ha, while a recent national survey estimates the area covered by the main forest type at 47,000 ha (National Academy of Sciences of the Kyrgyz Republic 2009).

Today, these forests form a rich cultural landscape, comprising a mosaic of natural and planted forest stands, fields, pastures and drier open areas (Beer et al. 2008; Schmidt \& Doerre 2011). As grazing animals are widespread (principally cattle, but also horses, sheep and goats), the prevailing land use could be described as a form of silvo-pastoral system (Gottschling et al. 2005; Beer et al. 2008). Other human impacts include hay-making in forest glades and meadows, harvesting of firewood, nuts, fruits, other non-timber products and some exploitation of timber (Musuraliev 1998; Gottschling et al. 2005; Schmidt 2005). Rural livelihoods depend strongly on the harvest of forest products, both for consumption and sale (Schmidt 2006). The forests also play a major role in soil protection and in regulating water flow, which is crucial for the irrigation of the fertile Fergana Valley (Musuraliev 1998).

The initial stimulus for this research was provided by a regional assessment of the conservation status of trees in Central Asia, undertaken in 2006. The International Union for Conservation of Nature (IUCN) Red List of Threatened Species (www.redlist.org) is widely recognised to be the most authoritative global assessment of the conservation status of species (Rodrigues et al. 2006; Mace et al. 2008). The list assesses species conservation status according to five quantitative criteria: (A) declining population size; (B) geographic range size; (C) small population size and decline; (D) very small or restricted population size and (E) quantitative analysis of extinction risk. Taxa that meet the appropriate threshold for at least one of the five criteria may be evaluated as critically endangered $(\mathrm{CR})$, endangered (EN) or vulnerable (VU). Together CR, EN and VU categories are 
described as 'threatened'. Taxa failing to meet the thresholds may be evaluated as near threatened (NT), least concern (LC) or data deficient (DD). A taxon is categorised as Extinct (EX) when there is no reasonable doubt that the last individual has died (IUCN 2001). The first Red List assessment of Central Asian tree species evaluated some 96 taxa, of which 44 were considered to be threatened with extinction, according to the Red List criteria (Eastwood et al. 2009). More than half of those considered threatened were accorded the highest category of threat $(\mathrm{CR})$, reflecting the fact that many are narrow endemics (Eastwood et al. 2009). While walnut was considered to be NT rather than at immediate risk of extinction, a number of fruit and nut tree species were classified as threatened. These included species of almond (Amygdalus spp.), apple (Malus spp.), apricot (Armeniaca spp.), cherry and plum (Prunus spp.), currant (Ribes spp.), hawthorn (Crataegus spp.) and pear (Pyrus spp.). The forests of the Tien Shan, especially those near rural settlements, were considered to be among the most threatened in the region (Eastwood et al. 2009).

As with many other Red List assessments of tree species (Newton \& Oldfield 2008), detailed information is lacking on the status and distribution of most tree species in the region. The results of this assessment are therefore uncertain. To address this knowledge gap, the research described here was undertaken to provide a preliminary assessment of the distribution and conservation status of selected fruit and nut tree species in Kyrgyzstan. This was achieved through a field survey throughout the range of walnut-fruit forests in this country, supported by a socio-economic survey of human use of these species.

\section{Methods}

Research was conducted in Jalal-Abad and Osh regions (oblasts), in the western Tien Shan mountains of Kyrgyzstan covering an area from $40^{\circ} 50^{\prime} 45^{\prime \prime}$ to $41^{\circ} 52^{\prime} 23^{\prime \prime} \mathrm{N}$ and $71^{\circ} 52^{\prime} 28^{\prime \prime}$ to $73^{\circ} 39^{\prime} 2^{\prime \prime} \mathrm{E}$ (Figure 1). The elevation ranged between 1097 and $1887 \mathrm{~m}$, with a mean elevation of $1459 \mathrm{~m}(\mathrm{SD} \pm 171 \mathrm{~m})$.

The following species were selected for survey on the basis of their IUCN Red list status: Amygdalus bucharica Korsh. (VU), Armeniaca vulgaris Lam. (EN), Crataegus pontica C. Koch (LC), M. sieversii (Ledeb.) M. Roem. (VU), Malus niedzwetzkyana Dieck. (EN), Pistacia vera L. (NT), Pyrus korshinskyi Litv. (CR), Sorbus persica Hedl. (LC) (Eastwood et al. 2009). In addition, Pyrus pyraster (L.) Burgsd., Pyrus turcomanica Maleev. and Vitis usunachmatica Vass. were included as these species are believed to be threatened with extinction in some areas, although information about their current global status is lacking (NE) (Eastwood et al. 2009). P. pyraster and P. turcomanica are of uncertain taxonomic status and were referred to the same taxon because of the difficulty of differentiating them consistently in the field. They are henceforth referred to as $P$. pyraster agg.

Field surveys for assessing the conservation status of the selected tree species were undertaken from 3 June 2010 to 23 September 2011 in 10 forest locations. Sample plots were located using a stratified random approach. First, areas of walnut-fruit forests believed to contain populations of one or more of these species were identified in consultation with local people and forest service staff. Locations identified were: (1) AkTerek, a research area of the Nut and Fruit Institute of the National Academy of Sciences of the Kyrgyz Republic (NAS KR); (2) Arslanbob leskhoz (forest enterprise); (3) Avletim leskhoz; (4) Dashman zakaznik (state conservation area); (5) Gaba leskhoz; (6) Kara-Alma leskhoz; (7) Kyzyl-Unkur leskhoz; (8) Salamalik, part of Uzgen leskhoz; (9) Sary-Chelek Biosphere Reserve; (10) Urumbash lesnichestvo (forest range) (Figure 1). A total of 116 sample plots were then located randomly within these forest locations (Table 1). The 
Table 1. Locations and areas (in hectares) identified by local people and forest service staff containing one or more of the species selected for this study (see text for details), and number of randomly located plots surveyed within these areas (one plot per 170 ha of area identified).

\begin{tabular}{lccc}
\hline Sites & $\begin{array}{c}\text { Area (ha) identified } \\
\text { by local people }\end{array}$ & $\begin{array}{c}\text { Number of plots } \\
\text { surveyed }\end{array}$ & $\begin{array}{c}\text { Percentage of the } \\
\text { area identified }\end{array}$ \\
\hline Ak-Terek & 2049 & 12 & 0.12 \\
Arslanbob & 854 & 5 & 0.12 \\
Avletim & 2903 & 17 & 0.12 \\
Dashman & 2220 & 13 & 0.12 \\
Gaba & 1537 & 9 & 0.12 \\
Kara-Alma & 1366 & 8 & 0.12 \\
Kyzyl-Unkur & 1537 & 9 & 0.12 \\
Salamalik & 683 & 4 & 0.12 \\
Sary-Chelek & 6148 & 36 & 0.12 \\
Urumbash & 512 & 3 & 0.12 \\
Total & 19,810 & 116 & \\
\hline
\end{tabular}

generation of random points was performed using the ESRI Hawth's Analysis Tools (C)2007 Version 3.27 extension within ArcGIS (C) 1999-2010 ESRI Inc., Redlands, CA, USA). The points were located in the field using a Global Position System device (Garmin GPS VII, Garmin (Europe) Ltd, Southampton, UK).

Square plots of 0.25 ha were used for the field survey, orientated on a northern axis. In some cases (18\% of the plots), where terrain and vegetation conditions were adverse, the plot size was reduced; therefore the mean plot size equalled 0.21 ha ( $\mathrm{SD} \pm 0.08 \mathrm{ha}$ ). Within each plot, the diameter at breast height ( $\mathrm{dbh}$ ) of each individual adult tree $(\geq 10 \mathrm{~cm} \mathrm{dbh})$ of the selected species was recorded using a diameter tape (Yamaho Million 12, Yamayo Measuring Tools Co., Ltd, Tokyo, Japan). Trees with multiple stems were recorded individually and counted as separate stems. Nested subplots at the southeast corner of the main plot were used to measure densities of seedlings and saplings. These subplots varied in size (0.01-0.25 ha) depending on the number of seedlings and saplings present within the plot. Seedlings were counted as all trees $\leq 1.5 \mathrm{~m}$ in height, and saplings were defined as individuals $>1.5 \mathrm{~m}$ in height but $\leq 10 \mathrm{~cm} \mathrm{dbh}$, following Newton (2007a). Values were used to calculate densities per hectare. Within each plot, measurements of human disturbance were also recorded. This consisted of noting the presence of any tracks or burning within the plot and any evidence of tree cutting and browsing impacts. Browsing impacts were assessed based on a list of indicators provided by Reimoser et al. (1999) and Rooney and Waller (2003) and included (i) the presence of browsing on seedlings, saplings and tree twigs, (ii) the presence of a browse line (i.e. horizontal line below which there is no growth on mature trees) and (iii) the presence of browsing animals.

To assess patterns of use of the selected tree species by local people, a socio-economic survey was undertaken. A total of 135 semi-structured interviews were carried out in three study areas, namely Sary-Chelek, Kara-Alma and Arslanbob $(n=45$ in each location), respectively located towards the western, centre and eastern areas of the walnut-fruit forests geographical range (Figure 1). These three study areas were chosen based on their different availability of forest resources per person; the highest and the lowest areas in terms of forest available per local resident were Kara-Alma (4.9 ha per person) and Arslanbob (0.45 ha per person), respectively (Jalilova \& Vacik 2012), whereas SaryChelek had 1.2 ha of forested area per person (Cantarello et al. 2014). Interviews were undertaken in Russian using a standardised questionnaire in which respondents were asked a series of pre-established questions with pre-set response categories (Bajracharya et al. 
2006). The purpose of the questionnaire was to determine the extent of harvesting, grazing practices and use of forest products. Questions invited respondents to score the intensity of use of different products using a four-point Likert scale. Respondents were also asked how the availability of different resources had changed over the previous 10 years, on a threepoint Likert scale (Cantarello et al. 2014).

Statistical analyses were performed using IBM SPSS Statistics v19 (C) 1989-2010, SPSS Inc., New York, USA). Descriptive statistics were calculated to describe the distribution of the selected species as seedlings, saplings and as adult trees (mean $\pm \mathrm{SE}$ ), the frequency of the human disturbances observed and the Likert scores elicited using the questionnaire (mean $\% \pm \mathrm{SE}$ ).

\section{Results}

\section{Distribution of species and stand structure}

$M$. sieversii and $P$. pyraster agg. were the most widely distributed species. $M$. sieversii was the only species that was found in all locations as seedlings, saplings and as adult trees, whereas $P$. pyraster agg. was found in six of the 10 locations as seedlings, five as saplings and seven as an adult tree. The remaining selected species were recorded in a much lower percentage of the sites. $C$. pontica and $P$. vera were only found as adult trees in one and two of the 10 locations, respectively. Of the 10 locations, Avletim contained the highest number of species, whereas Urumbash contained the lowest (Table 2).

The mean density of seedling varied markedly between species. Within the plots where seedlings were found, the lowest value was recorded for $P$. pyraster agg. with eight seedling ha ${ }^{-1}$, and the highest for $M$. sieversii with 1233 seedling ha ${ }^{-1}$. High variability in the mean seedling density was also recorded within species, values ranging from 46 seedling ha ${ }^{-1}$ to 1233 seedling ha ${ }^{-1}$ for $M$. sieversii and from eight seedling ha ${ }^{-1}$ to 689 seedling ha ${ }^{-1}$ for $P$. pyraster agg. Within the plots where saplings were found, the lowest mean density ranged from 1 sapling ha ${ }^{-1}$ for $P$. pyraster agg. to 144 saplings ha $^{-1}$ for $M$. sieversii (Table 3).

When data from all of the plots were pooled for analysis, only M. sieversii was found to be represented in the majority of the dbh classes. Stand structure of this species revealed a pronounced inverse J-shape (Figure 2), implying continuous recruitment (Newton 2007a). Many of the other tree species were present only in the smaller and larger dbh classes, including A. vulgaris, C. pontica, M. niedzwetzkyana, P. korshinskyi and $S$. persica (Figure 2).

\section{Human disturbance and local use}

Human impacts were widespread in all of the forest locations. A high overall mean percentage of plots featured tracks $(98 \% \pm$ SE 1.3), had browsing animals present (89\% \pm SE 4.4), had signs of browsing on trees species (75\% \pm SE 7.9) and of tree cutting $(84 \% \pm$ SE 6.9). Signs of burning and a browse line on mature trees were observed in all of the surveyed plots (100\%) in six and three of the 10 locations, respectively. Arslanbob featured the highest mean frequency of the human disturbances observed (96\% $\pm \mathrm{SE} 4.2)$, whereas Urumbash the lowest (59\% \pm SE 19) (Table 4).

The semi-structured interviews conducted in Arslanbob, Kara-Alma and Sary-Chelek identified several ways in which the forest is being used by the local communities. With regard to the grazing practices, $97 \%$ of the respondents (131 out of 135) stated that they allow livestock (mainly cattle, but also horses and sheep) into the forest. A large 
Table 2. Presence $(X)$ or absence $(-)$ of data of the species assessed in the surveyed plots (number in brackets) in each of the 10 sites, either as an adult tree, seedling, sapling or tree.

\begin{tabular}{|c|c|c|c|c|c|c|c|c|c|c|c|c|}
\hline \multirow[b]{2}{*}{ Species } & & \multicolumn{11}{|c|}{ Sites } \\
\hline & & 1 & 2 & 3 & 4 & 5 & 6 & 7 & 8 & 9 & 10 & Total \\
\hline \multirow[t]{3}{*}{ A. bucharica } & Seedlings & - & - & - & $X$ & $\mathrm{X}$ & - & - & $\mathrm{X}$ & - & - & 3 \\
\hline & Saplings & - & - & $\mathrm{X}$ & $\mathrm{X}$ & - & - & - & $X$ & - & - & 3 \\
\hline & Trees & - & - & - & $\mathrm{X}$ & $X$ & & - & $\mathrm{X}$ & - & - & 3 \\
\hline \multirow[t]{3}{*}{ A. vulgaris } & Seedlings & - & - & $\mathrm{X}$ & - & - & - & - & - & - & - & 1 \\
\hline & Saplings & - & - & - & - & - & - & - & $\mathrm{X}$ & $X$ & - & 2 \\
\hline & Trees & $\mathrm{X}$ & - & X & - & - & - & - & X & $X$ & - & 4 \\
\hline \multirow[t]{3}{*}{ C. pontica } & Seedlings & - & - & - & - & - & - & - & - & - & - & 0 \\
\hline & Saplings & - & - & - & - & - & - & - & - & - & - & 0 \\
\hline & Trees & $\mathrm{X}$ & - & - & - & - & - & - & - & - & - & 1 \\
\hline \multirow[t]{3}{*}{ M. sieversii } & Seedlings & $\mathrm{X}$ & $\mathrm{X}$ & $\mathrm{X}$ & $\mathrm{X}$ & $\mathrm{X}$ & $X$ & $\mathrm{X}$ & $\mathrm{X}$ & $X$ & $\mathrm{X}$ & 10 \\
\hline & Saplings & $\mathrm{X}$ & $\mathrm{X}$ & $\mathrm{X}$ & $\mathrm{X}$ & $\mathrm{X}$ & $X$ & $\mathrm{X}$ & $\mathrm{X}$ & $X$ & $X$ & 10 \\
\hline & Trees & $\mathrm{X}$ & X & X & $\mathrm{X}$ & $\mathrm{X}$ & $X$ & X & X & $X$ & X & 10 \\
\hline \multirow[t]{3}{*}{ M. niedzwetzkyana } & Seedlings & - & - & - & - & - & $X$ & - & - & - & - & 1 \\
\hline & Saplings & - & - & - & - & - & - & - & - & $X$ & - & 1 \\
\hline & Trees & $\mathrm{X}$ & - & $\mathrm{X}$ & - & - & $\mathrm{X}$ & - & - & $\mathrm{X}$ & - & 4 \\
\hline \multirow[t]{3}{*}{$P$. vera } & Seedlings & - & - & - & - & - & - & - & - & - & - & 0 \\
\hline & Saplings & - & - & - & - & - & - & - & - & - & - & 0 \\
\hline & Trees & - & $\mathrm{X}$ & $\mathrm{X}$ & - & - & - & - & - & - & - & 2 \\
\hline \multirow[t]{3}{*}{ P. korshinskyi } & Seedlings & $\mathrm{X}$ & - & - & - & - & - & - & - & - & - & 1 \\
\hline & Saplings & $\mathrm{X}$ & - & - & - & - & - & - & - & - & - & 1 \\
\hline & Trees & $\mathrm{X}$ & - & $\mathrm{X}$ & - & - & - & $\mathrm{X}$ & - & - & - & 3 \\
\hline \multirow[t]{3}{*}{$P$. pyraster agg. } & Seedlings & $\mathrm{X}$ & - & X & $X$ & $\mathrm{X}$ & - & $\mathrm{X}$ & - & $X$ & - & 6 \\
\hline & Saplings & $\mathrm{X}$ & - & $X$ & $X$ & - & - & $\mathrm{X}$ & - & $X$ & - & 5 \\
\hline & Trees & $\mathrm{X}$ & - & $\mathrm{X}$ & $\mathrm{X}$ & $\mathrm{X}$ & X & $\mathrm{X}$ & - & $X$ & - & 7 \\
\hline \multirow[t]{3}{*}{ S. persica } & Seedlings & - & - & - & - & - & - & - & - & $X$ & - & 1 \\
\hline & Saplings & - & - & - & $X$ & - & - & - & - & - & - & 1 \\
\hline & Trees & - & - & - & $\mathrm{X}$ & - & - & - & - & - & - & 1 \\
\hline \multirow[t]{3}{*}{ V. usunachmatica } & Seedlings & - & - & $\mathrm{X}$ & - & - & $X$ & $\mathrm{X}$ & - & - & - & 3 \\
\hline & Saplings & - & - & - & - & - & $X$ & - & - & - & - & 1 \\
\hline & Trees & - & $X$ & $\mathrm{X}$ & - & - & $X$ & $X$ & - & $X$ & $X$ & 6 \\
\hline $\begin{array}{l}\text { Total no. sites with } \\
\text { seedlings }\end{array}$ & & 3 & 1 & 3 & 4 & 1 & 2 & 2 & 3 & 4 & 1 & \\
\hline $\begin{array}{l}\text { Total no. sites with } \\
\text { saplings }\end{array}$ & & 2 & 0 & 3 & 3 & 1 & 2 & 3 & 0 & 3 & 0 & \\
\hline $\begin{array}{l}\text { Total no. sites with } \\
\text { trees }\end{array}$ & & 6 & 3 & 7 & 4 & 3 & 4 & 4 & 3 & 5 & 2 & \\
\hline
\end{tabular}

Notes: 1, Ak-Terek (12); 2, Arslanbob (5); 3, Avletim (17); 4, Dashman (13); 5, Gaba (9); 6, Kara-Alma (8); 7, Kyzyl-Unkur (9); 8, Salamalik (4); 9, Sary-Chelek (36); 10, Urumbash (3).

proportion of the respondents (44-63\%) stated that their livestock walked less than $5 \mathrm{~km}$ away from their farm, with the remaining (37-56\%) reporting a distance $>5 \mathrm{~km}$. The majority (60\%) of the respondents believed that in the past 10 years, the distance livestock have to walk to find grazing areas had stayed the same, whereas $39 \%$ perceived the distance to have increased. The number of livestock was reported to have increased in $51 \%$ of households and stayed the same in $38 \%$. The majority $(65 \%)$ of the respondents perceived the area available for grazing to have decreased, whereas $28 \%$ believed that the grazing area has stayed the same. The opinions with regard to the quality of the grazing areas in the forest differed, with $36 \%$ indicating that it had remained constant, $33 \%$ that it had increased and $24 \%$ that it had decreased (Table 5). 

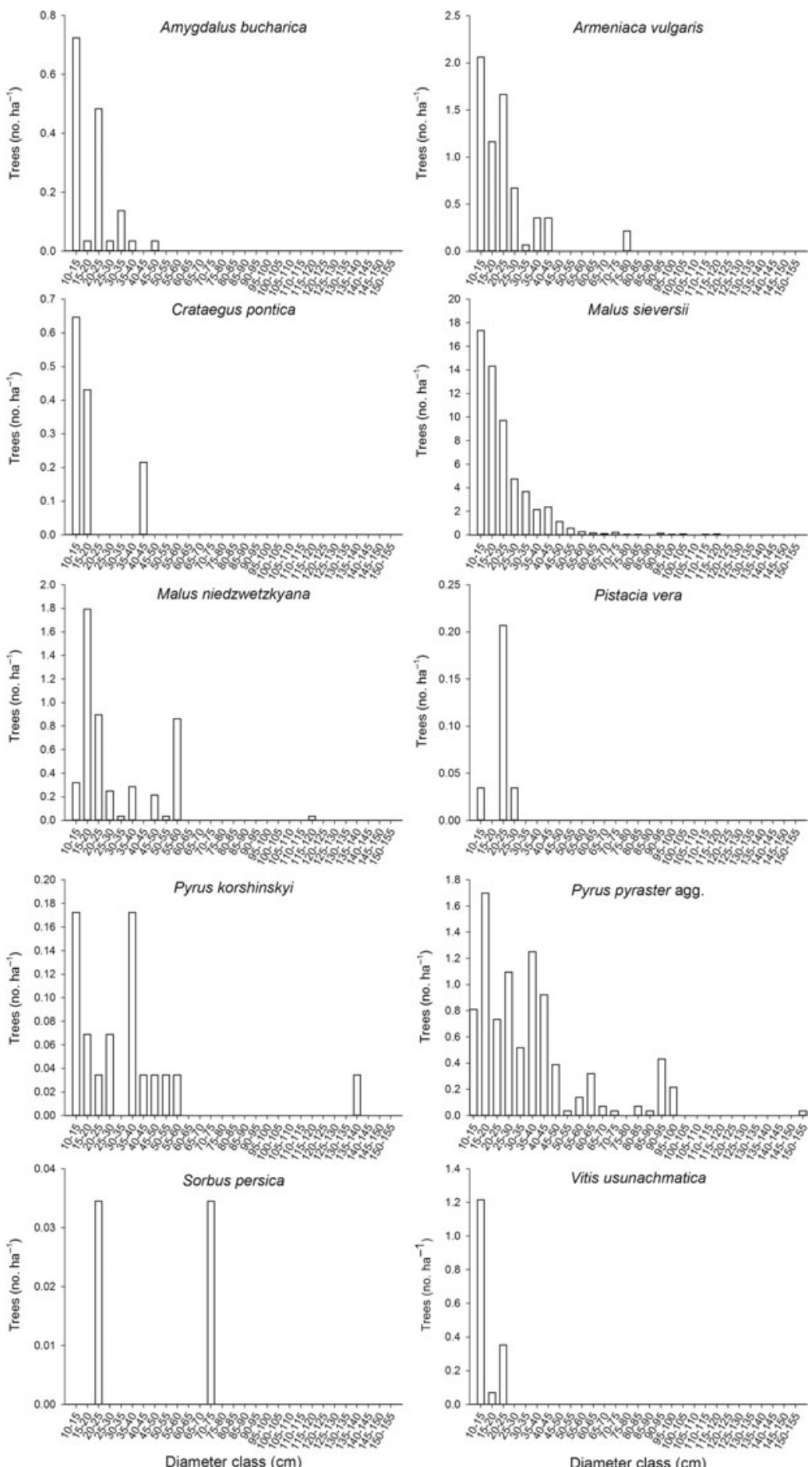

Figure 2. Mean density of tree species assessed in the field survey (see text). Size structure for the forest trees was examined by grouping the trees into different size classes, each of $5 \mathrm{~cm}$ for every tree over $10 \mathrm{~cm} \mathrm{dbh}$. 
Table 4. Human disturbances assessed in the field survey (see text).

\begin{tabular}{|c|c|c|c|c|c|c|c|c|c|c|}
\hline \multirow[b]{2}{*}{ Human disturbance } & \multicolumn{10}{|c|}{ Sites } \\
\hline & 1 & 2 & 3 & 4 & 5 & 6 & 7 & 8 & 9 & 10 \\
\hline Tracks & 100 & 100 & 100 & 95 & 100 & 100 & 92 & 100 & 89 & 100 \\
\hline Burning & 8 & 100 & 100 & 100 & 100 & 10 & 17 & 100 & 100 & 17 \\
\hline $\begin{array}{l}\text { Presence of browsing on } \\
\text { seedlings, saplings and tree } \\
\text { twigs }\end{array}$ & 100 & 100 & 70 & 95 & 93 & 70 & 67 & 60 & 78 & 17 \\
\hline $\begin{array}{l}\text { Browse line on mature } \\
\text { trees }\end{array}$ & 100 & 100 & 73 & 63 & 87 & 60 & 42 & 20 & 56 & 17 \\
\hline Presence of browsing animals & 100 & 100 & 90 & 100 & 93 & 70 & 92 & 60 & 89 & 100 \\
\hline Tree cutting & 100 & 75 & 100 & 100 & 93 & 100 & 83 & 40 & 53 & 100 \\
\hline
\end{tabular}

Note: Values presented are percentages of the presence of each disturbance measure in the surveyed plots in each of the 10 sites (number of plots given in brackets).

1, Ak-Terek (12); 2, Arslanbob (5); 3, Avletim (17); 4, Dashman (13); 5, Gaba (9); 6, Kara-Alma (8); 7, KyzylUnkur (9); 8, Salamalik (4); 9, Sary-Chelek (36); 10, Urumbash (3).

Table 5. Opinions of respondents on their grazing practices assessed during the socio-economic survey.

\begin{tabular}{|c|c|c|c|c|c|c|}
\hline & \multicolumn{2}{|c|}{$\mathrm{AR}$} & \multicolumn{2}{|c|}{ KA } & \multicolumn{2}{|r|}{ SC } \\
\hline & $\%$ & Cat. & $\%$ & Cat. & $\%$ & Cat. \\
\hline $\begin{array}{l}\text { Do you allow your grazing animals } \\
\text { to enter the forest? }\end{array}$ & 91 & Yes & 100 & Yes & 100 & Yes \\
\hline \multirow{2}{*}{$\begin{array}{l}\text { How far do the animals go } \\
\text { from your farm? }\end{array}$} & 63 & $<5 \mathrm{~km}$ & 56 & $>5 \mathrm{~km}$ & 62 & $<5 \mathrm{~km}$ \\
\hline & 33 & $>5 \mathrm{~km}$ & 44 & $<5 \mathrm{~km}$ & 31 & $>5 \mathrm{~km}$ \\
\hline \multirow{2}{*}{$\begin{array}{l}\text { How has the distance walked by } \\
\text { grazing animals from your farm changed } \\
\text { over the past } 10 \text { years? }\end{array}$} & 82 & $\Leftrightarrow$ & 67 & 仓 & 64 & $\Leftrightarrow$ \\
\hline & 18 & 仓 & 33 & $\Leftrightarrow$ & 31 & 仓 \\
\hline \multirow{2}{*}{$\begin{array}{l}\text { How has the number of animals } \\
\text { that you own changed over the } \\
\text { past } 10 \text { years? }\end{array}$} & 67 & 仓 & 49 & $\Leftrightarrow$ & 48 & 仓 \\
\hline & 24 & $\Leftrightarrow$ & 38 & 仓 & 40 & $\Leftrightarrow$ \\
\hline \multirow{2}{*}{$\begin{array}{l}\text { How has the area available for } \\
\text { grazing in the forest changed over } \\
\text { the past } 10 \text { years? }\end{array}$} & 76 & Л & 67 & $\sqrt{2}$ & 53 & ת \\
\hline & 24 & $\Leftrightarrow$ & 27 & $\Leftrightarrow$ & 33 & $\Leftrightarrow$ \\
\hline \multirow{3}{*}{$\begin{array}{l}\text { How has the quality of grazing } \\
\text { in the forest changed over the } \\
\text { past } 10 \text { years? }\end{array}$} & 64 & $\Leftrightarrow$ & 62 & 仓 & 51 & $\sqrt{2}$ \\
\hline & 36 & 仓 & 20 & Л & 29 & $\Leftrightarrow$ \\
\hline & & & 16 & $\Leftrightarrow$ & 20 & Don't know \\
\hline
\end{tabular}

Notes: Forty-five people were interviewed in each area. Note that opinions indicated by $<10 \%$ of respondents have been omitted, for clarity.

AR, Arslanbob; KA, Kara-Alma and SC, Sary-Chelek. \%, percentage of respondents, Cat., category. 仓, increase, $\Omega$, decrease, $\Leftrightarrow$, stayed the same.

Regarding the local use of forest products, the respondents were first asked which of the selected species they collected from the forest. A total of $80 \%$ of the respondents reported gathering Malus sp. occasionally for their fruits. Pyrus sp. was also mentioned by the 
respondents $(9 \%)$ to be harvested for their fruits, but only rarely. No respondents classified their fruit collection as often. The vast majority of the respondents $(82 \%)$ said that they collected fruits for their own subsistence. The respondents (40\%) most frequently travelled between 30 and 60 minutes by foot to arrive at the location where they collected fruits. Of the respondents, 30\% travelled between 60 and 120 minutes and 19\% travelled less than 30 minutes. Over the past 10 years, the majority of the respondents $(66 \%)$ noted that the time needed to reach a location where fruits could be collected had remained constant, whereas $33 \%$ of the respondents said that the time had increased. A high percentage of the respondents $(54 \%)$ pointed out that the amount of fruits harvested had decreased over the past 10 years and $28 \%$ indicated that it has stayed the same. Similarly, the majority of the respondents $(51 \%)$ noted that there had a decrease in the availability of fruits in the past 10 years, and $45 \%$ of the respondents said that it had remained constant (Table 6).

Regarding fuelwood collection, Malus sp. and Crataegus sp. were reported to be harvested occasionally by $76 \%$ and $49 \%$ of the respondents, respectively. No respondents classified the frequency of their firewood collection as often. The vast majority of the respondents $(88 \%)$ indicated that they harvested fuelwood for subsistence. Almost equal proportions of the respondents $(39 \%$ and $40 \%)$ reported collection of fuelwood with stem diameters between $5-10$ and $10-20 \mathrm{~cm} ; 13 \%$ and $8 \%$ of the respondents said that they harvested fuelwood with diameter $<5$ and $20-50 \mathrm{~cm}$, respectively. The most frequent travel time $(64 \%)$ in order to arrive at a location where fuelwood could be collected was 3060 minutes. Some respondents $(21 \%)$ indicated a travel time between 30-60 minutes and only few $(13 \%)$ stated that they had to travel $>120$ minutes to collect fuelwood. Over the last 10 years, a majority of the respondents $(76 \%)$ noted an increase in the time needed to find a source of fuelwood, whereas others (21\%) indicated that the time had stayed the same. Of the respondents, $64 \%$ pointed out that the amount of fuelwood harvested had decreased over the past 10 years, $21 \%$ that it had increased and $15 \%$ that it had stayed the same. However, a high percentage $(92 \%)$ of the respondents indicated that there had been a decrease in the availability of fuelwood in the past 10 years, with only 5\% suggesting an increase (Table 6).

In only one location (Arslanbob) did the respondents (100\%) report harvesting Malus sp. for timber. All respondents indicated that they harvested timber rarely and for subsistence only. The most frequent (98\%) diameter harvested was between 10 and $20 \mathrm{~cm}$. The time spent travelling to the source of timber was $60-120$ minutes for $71 \%$ of the respondents and 30-60 minutes for the remaining 29\%. Of the respondents, $56 \%$ noted that the time needed to travel to a source of timber had stayed the same in the last 10 years, whereas $40 \%$ reported an increase. The majority (58\%) of the respondents pointed out that in the past 10 years, the amount of timber harvested had stayed the same, whereas others $(38 \%)$ noted a decrease. Of the respondents, $91 \%$ considered the availability of timber to have decreased during this time.

\section{Discussion}

This study presents the first field-based assessment of the distribution and status of threatened fruit tree species in the walnut-fruit forests of Kyrgyzstan. The results indicate that the surveyed species vary markedly in abundance. Strikingly, M. sieversii was found to be widespread, occurring in each of the 10 locations surveyed as both seedlings and saplings, and as adult trees. In addition, this species was the most abundant of those surveyed within individual sites, recording the highest mean density of adult trees, saplings and seedlings. Regeneration appears to be copious, with no evidence of recruitment limitation or failure. These results suggest that although this species is 
A. Orozumbekov et al.

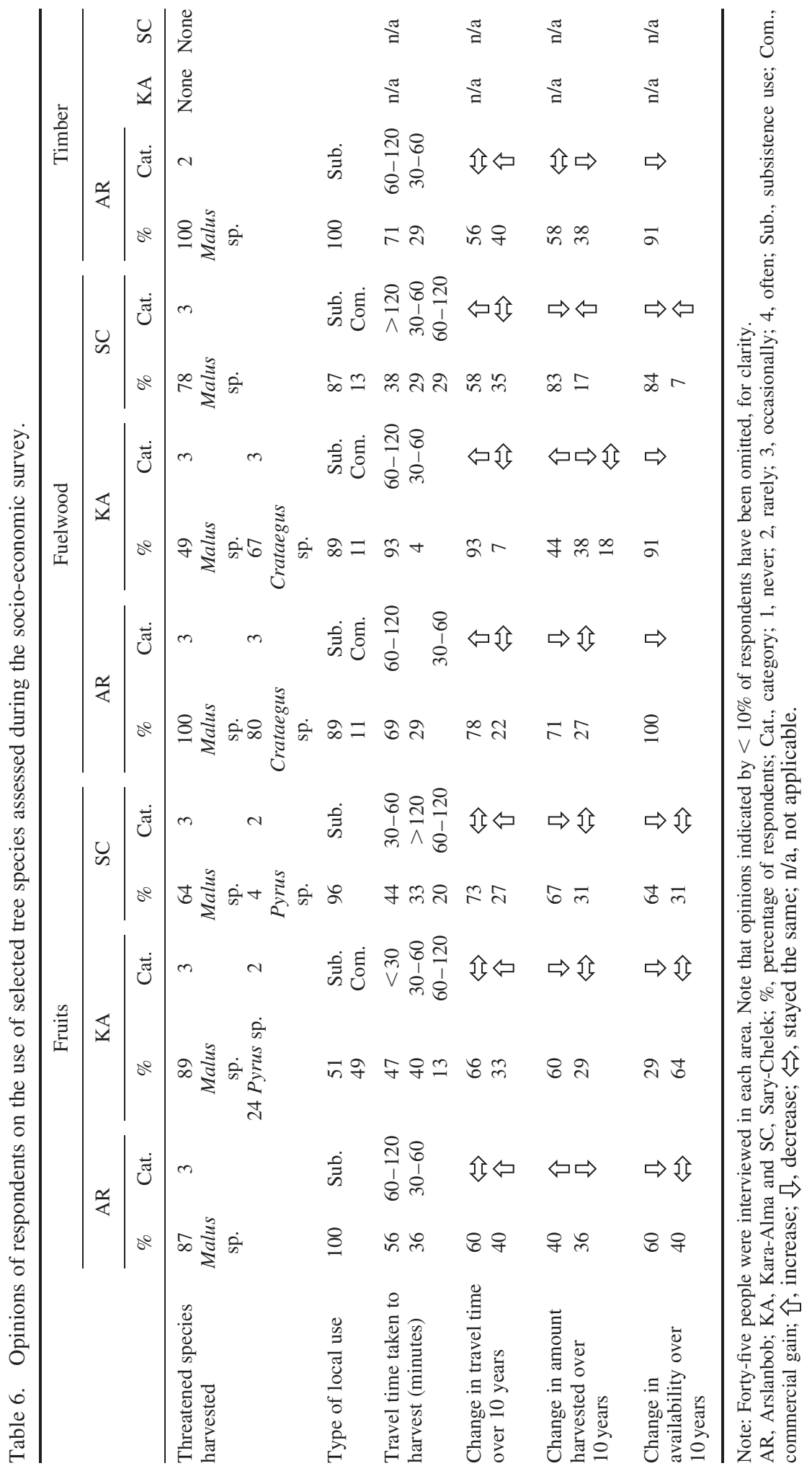


categorised as VU on the IUCN Red List (Eastwood et al. 2009), it is perhaps unlikely to be under immediate threat of extinction and might reasonably be accorded lower priority for conservation action than some of the other species considered here. In contrast, $P$. korshinskyi, which is listed as CR by Eastwood et al. (2009), was found to be very scarce either as an adult tree or a juvenile. Other species with very low abundance (i.e. present on $\leq 20 \%$ of sites) included $C$. pontica (listed as LC by Eastwood et al. 2009), P. vera (NT) and $S$. persica (LC). Other species considered threatened with extinction by Eastwood et al. (2009), namely A. bucharica (VU), A. vulgaris (EN) and $M$. niedzwetzkyana (EN), were each found on $40 \%$ of sites either as an adult and/or juvenile. Although mean densities of these species were relatively low, as both adults and juveniles, evidence of regeneration was observed on at least one site in each case. Species not evaluated by Eastwood et al. (2009), namely P. pyraster and V. usunachmatica, were each found to be relatively widespread (i.e. present on $\geq 60 \%$ of sites) and occurred at moderate densities, although density of saplings was very low in the latter species.

The limitations of the survey method should clearly be borne in mind when interpreting these results. Ideally, a comprehensive and systematic survey of all remnant forest areas would be carried out to accurately determine the current status of these species. Currently, the scope for such a survey is very limited, owing to the lack of capacity and resources available within Kyrgyzstan. The sampling approach adopted here has the advantage of providing preliminary evidence of population density in areas where the species are known to occur, but the use of local knowledge to stratify the sampling sites might have biased estimates of overall abundance. This may have particularly been the case with $M$. sieversii, which emerged as the principal fruit tree species harvested by local communities, and is therefore likely to have been the best known of the species surveyed. Although participatory approaches to biodiversity assessment are increasingly being implemented, which make use of local knowledge, their potential limitations and biases are widely recognised (Cooke \& Kothari 2001). In addition, taxonomic uncertainties exist between $M$. sieversii (Lebed.) M. Roem and M. pumila Mill.; while according to the classification of wild apples species presented in Juniper and Mabberley (2006), these two species are the same, recent evidence suggests that this may not be the case (Cornille et al. 2012). Clearly, the current results do not provide a robust assessment of the geographical range of each species within Kyrgyzstan, which is required to strengthen the Red List assessment (IUCN 2001), but the data do at least provide an initial indication of their relative abundance within the sites surveyed.

The data collected on stand structure provide some initial insights into the age structure, and therefore population dynamics of these species. A number of species (such as $C$. pontica, $M$. niedzwetzkyana, $P$. korshinskyi and S. persica) showed some evidence of a bimodal distribution of stem diameters (i.e. trees present primarily in the smaller and larger dbh classes). This could be attributable to the removal of intermediate size classes of these species for fuelwood, at least in part, as supported by the results of the socioeconomic survey. Most previous research on the walnut-fruit forests (Blaser et al. 1998) has focused on the dominant species J. regia, as the collection of walnuts and timber production can be a major source of income for local people (Fisher et al. 2004). However, little attention has previously been given to the fruit species associated with walnut, which as noted here, may often be of greater conservation concern. This study provides the first evidence that fuelwood collection might be impacting the age structure and potentially the distribution of threatened fruit species, suggesting a need to address such harvesting within forest management plans. However, the bimodal distribution of stem diameters also may be attributable to episodic regeneration associated with favourable light condition for seed 
establishment and subsequent development of seedlings, saplings and adult trees. Many of the fruit species of walnut-fruit forests of Kyrgyzstan are believed to be light demanding and may therefore require canopy disturbance for establishment (Cantarello et al. 2014). This is consistent with the 'gap dynamic theory' which predicts shade-tolerant species to become established within gaps in the forest canopy created by natural disturbances (Yamamoto 2000). However, a detailed examination of patterns of regeneration and gap colonisation by fruit tree species would be necessary to elucidate this point, as for example described in Eichhorn (2010).

The results presented here indicated that mean seedling and sapling densities of most species were relatively low, a finding that is consistent with the scarce natural regeneration reported for walnut in many walnut-fruit forests of Kyrgyzstan (Kolov 1998; Venglovsky 1998; Gottschling et al. 2005). Lack of walnut regeneration has commonly been attributed to overgrazing, a suggestion that our study also seems to support in relation to fruit tree species. Our field survey found that browsing impacts were widespread in all of the forest locations, and the socio-economic survey indicated that livestock grazing in the forest is a very common practice. Jalilova and Vacik (2012) indicated that local people in this study area seem to be unaware of the potential impacts of browsing on forest species. The current study provides the first evidence that the current levels of grazing might be inhibiting the regeneration of threatened fruit species, in addition to walnut. However, further observations of the impacts of browsing on the survival and growth of juvenile trees are required to test this assertion. In contrast to the other species, M. sieversii demonstrated a clear reverse-J stand structure that is indicative of continuous recruitment (Newton 2007a), despite the browsing pressure identified in all study areas. The ecology of Malus spp. is not well understood, but evidence suggests that the presence of large herbivores may actually enhance regeneration of these species in some situations (Juniper \& Mabberley 2006). For example, Buttenschøn and Buttenschøn (1999) found that in a study area in Denmark, domestic cattle and horses were found to be a major dispersal vector for Malus sylvestris, as well as providing suitable seedbeds for germination. However, survival rate of seedlings was inversely related to grazing pressure. Further research is required to determine the relative positive and negative impacts of livestock on recruitment of $M$. sieversii in Kyrgyzstan, but on the basis of results presented here, this species would appear to be able to regenerate successfully under the current livestock densities.

The results of the socio-economic survey provided evidence that both the availability and amount of fruits and fuelwood harvested have decreased in the past 10 years. In addition, the majority of survey respondents noted an increase in the time needed to find a source of fuelwood. Assuming that local people will travel the minimum distance needed, this finding indicates that fuelwood is being depleted and local people are now travelling further from their farms than a decade ago, in order to collect it. A change in the travel time to the resource provides a proxy for the sustainability of harvesting (Marshall \& Newton 2003) and implies unsustainable patterns of forest use in this area. This finding is supported by other research. According to a recent calculation undertaken in one location (i.e. Arslanbob), annual fuelwood consumption was found to be five times higher than the annual increment of the trees (Jalilova \& Vacik 2012). Results of modelling the dynamics of walnut-fruit forests also suggested that the current intensity of fuelwood harvesting is not sustainable (Cantarello et al. 2014). Fisher et al. (2004) and Schmidt (2012) pointed out that fuelwood and fruit collection have become increasingly important in the last 20 years in Kyrgyzstan, since the socio-economic recession following independence. This has resulted in increasing costs of energy sources other than fuelwood and lack of 
opportunities for salaried employment, which have forced more people to return to subsistence agriculture.

The findings of this study highlighted the need to regulate local use of walnut-fruit forests to ensure that such use is sustainable, and to identify appropriate conservation actions to conserve threatened fruit tree species. As noted by Cantarello et al. (2014) and Jalilova et al. (2012), this could potentially be achieved by adopting a participatory forest management approach, where local people are actively involved in forestry activities. In recent years, there has been increasing interest in such participatory approaches in many countries, illustrated by the CAMPFIRE project in Zimbabwe (Taylor 2009) and the development of Community Forest User Groups in Nepal (Lawrence et al. 2006). In order to introduce such approaches to Kyrgyzstan, such approaches will need to be adapted to the prevailing pattern of land ownership. Most forest land remains state-owned and is divided into territorial management enterprises called 'leshozes' that are managed by the State Forest Service. There is currently no ownership of forest land by local communities. Despite this, efforts to introduce participatory forest management approaches to Kyrgyzstan have been initiated (Carter et al. 2003; Carter et al. 2010). In recent years, Flora \& Fauna International (FFI), together with its local partner organisations, has facilitated the process of joint management planning through the organisation of participatory workshops for forestry staff and local community representatives, resulting in integrated management plans for three of the 10 locations surveyed by this study (i.e. Kara-Alma, Kyzyl-Unkur and Sary-Chelek). A key element to the success of participatory forest management is the role of monitoring, which can help local communities engage in land management (Danielsen et al. 2005) and support the development of adaptive management approaches (Newton 2008). Introduction of such participatory monitoring into joint management plans is an urgent priority if the tree species of walnut-fruit forest are to be effectively conserved. Management actions should also be developed to address the conservation needs of individual species. The current results support the suggestion of Eastwood et al. (2009) that $P$. korshinskyi should be accorded the highest priority for such action; other priority species might include A. bucharica, A. vulgaris and $M$. niedzwetzkyana. In contrast, $M$. sieversii appears to be of lower concern, which suggests that the extinction risk of this species may need to be reassessed.

\section{Acknowledgements}

The contribution of the following individuals to this research is gratefully acknowledged: Jennifer Birch, Alex Lovegrove, Jonathan Mace, Tom Alexander, Kevin Nakonechny, Kanaat Musuraliev and Niels Brouwers for assistance with fieldwork.

\section{Funding}

This research was funded by the UK Darwin Initiative, under the 'Conserving Eden: participatory forest management in the Tien Shan region' Project (Ref: 17001).

\section{Note}

1. Email: ecantarello@bournemouth.ac.uk

\section{References}

Bajracharya SB, Furley PA, Newton AC. 2006. Impacts of community-based conservation on local communities in the Annapurna Conservation Area, Nepal. Biodivers Conserv. 15:2765-2786. 
Beer R, Kaiser F, Schmidt K, Ammann B, Carraro G, Grisa E, Tinner W. 2008. Vegetation history of the walnut forests in Kyrgyzstan (Central Asia): natural or anthropogenic origin? Quater Sci Rev. 27:621-632.

Blaser J, Carter J, Gilmour D. 1998. Biodiversity and sustainable use of Kyrgyzstan's walnut-fruit forests. Gland, Bern: IUCN, Intercooperation.

Buttenschon RM, Buttenschon J. 1999. Population dynamics of Malus sylvestris stands in grazed and ungrazed, semi-natural grasslands and fragmented woodlands in Mols Bjerge, Denmark. Ann Bot Fenn. 35:233-246.

Cantarello E, Lovegrove A, Orozumbekov A, Birch J, Brouwers N, Newton AC. 2014. Human impacts on forest biodiversity in protected walnut-fruit forests in Kyrgyzstan [Internet]. J Sust. For [cited 19 March 2014]. Available from: http://dx.doi.org/10.1080/10549811.2014.901918

Carter J, Grisa E, Akenshaev R, Saparbaev N, Sieber P, Samyn J-M. 2010. Revisiting collaborative forest management in Kyrgyzstan: what happened to bottomup decision-making? Gatekeeper series no. 148. London: IIED.

Carter J, Steenhof B, Haldimann E, Akenshaev N. 2003. Collaborative forest management in Kyrgyzstan: moving from top-down to bottom-up decision-making. Gatekeeper series no. 108. London: IIED.

Cooke B, Kothari U, editors. 2001. Participation: the new tyranny? London: Zed Books.

Cornille A, Gladieux P, Smulders MJM, Roldan-Ruiz I, Laurens F, Le Cam B, Nersesyan A, Clavel J, Olonova M, Feugey L, et al. 2012. New insight into the history of domesticated apple: secondary contribution of the European wild apple to the genome of cultivated varieties. PLoS Genet. 8(5):e1002703.

Danielsen F, Burgess ND, Balmford A. 2005. Monitoring matters: examining the potential of locally-based approaches. Biodivers Conserv. 14:2507-2542.

Deakin R. 2007. Wildwood: a journey through trees. London: Penguin Books.

Eastwood A, Lazkov G, Newton A. 2009. The Red List of trees of Central Asia. Cambridge: Fauna \& Flora International.

Eichhorn MP. 2010. Spatial organisation of a bimodal forest stand. J For Res. 15:391-397.

Epple C. 2001. A vegetation study in the walnut and fruit-tree forests of Southern Kyrgyzstan. Phytocoenologia. 31:571-604.

Fisher RJ, Schmidt K, Steenhof B, Akenshaev N. 2004. Poverty and forestry: a case study of Kyrgyzstan with reference to other countries in West and Central Asia. LSP working paper 13. Rome: Food and Agriculture Organization.

Food and Agriculture Organization of the United Nations [FAO]. 2012. State of the world's forests 2012. Rome: FAO.

Gottschling H, Amatov I, Lazkov G. 2005. Zur Ökologie und Flora der Walnuss-Wildobst-Wälder in Süd-Kirgisistan [About the ecology and flora of walnut-fruit-forests of southern Kyrgyzstan]. Archiv für Naturschutz und Landschaftsforschung. 44:85-132.

Harris SA, Robinson JP, Juniper BE. 2002. Genetic clues to the origin of the apple. Trend Genet. 18:426-430.

Hemery GE, Popov SI. 1998. The walnut (Juglans regia L.) forests of Kyrgyzstan and their importance as a genetic resource. Commonwealth For Rev. 77:272-276.

Hutton JM, Leader-Williams N. 2003. Sustainable use and incentive-driven conservation: realigning human and conservation interests. Oryx. 37:215-226.

IUCN. 2001. IUCN Red List categories and criteria, version 3.1. Gland: IUCN SSC.

Jalilova G, Khadka C, Vacik H. 2012. Developing criteria and indicators for evaluating sustainable forest management: a case study in Kyrgyzstan. For Policy Econ. 21:32-43.

Jalilova G, Vacik H. 2012. Local people's perceptions of forest biodiversity in the walnut fruit forests of Kyrgyzstan. In J Biodivers Sci Ecosyst Serv Manag. 8:204-216.

Juniper BE, Mabberley DJ. 2006. The story of the apple. Oregon: Timber Press.

Juniper BE, Watkins R, Harris SA. 1998. The origin of the apple. In: Tobutt KR, Alston FH, editors. Eucarpia symposium on fruit breeding and genetics.

Kolov O. 1998. Ecological characteristics of the walnut-fruit forests of southern Kyrgyzstan. In: Blaser J, Carter J, Gilmour D, editors. Biodiversity and sustainable use of Kyrgyzstan's walnutfruit forests. Gland, Bern: IUCN, Intercooperation.

Lawrence A, Paudel K, Barnes R, Malla Y. 2006. Adaptive value of participatory biodiversity monitoring in community forestry. Environ Conserv. 33:325-334. 
Mace GM, Collar NJ, Gaston KJ, Hilton-Taylor C, Akcakaya HR, Leader-Williams N, MilnerGulland EJ, Stuart SN. 2008. Quantification of extinction risk: IUCN's system for classifying threatened species. Conserv Biol. 22:1424-1442.

Marshall E, Newton AC. 2003. Non-timber forest products in the community of El Terrero, Sierra de Manantlan Biosphere Reserve, Mexico: is their use sustainable? Econ Bot. 57:262-278.

McGranahan G, Leslie C. 1991. Walnuts (Juglans L.). In: Moore JN, Ballington JR, editors. Genetic resources of temperate fruit and nut crops. Wageningen: International Society for Horticultural Science.

Milner-Gulland EJ, Mace R. 1998. Conservation of biological resources. Oxford: Blackwell.

Musuraliev TM. 1998. Forest management and policy for the walnut-fruit forests of the Kyrgyz Republic. In: Blaser J, Carter J, Gilmour D, editors. Biodiversity and sustainable use of Kyrgyzstan's walnut-fruit forests. Gland, Bern: IUCN, Intercooperation.

Myers N, Mittermeier RA, Mittermeier CG, da Fonseca GAB, Kent J. 2000. Biodiversity hotspots for conservation priorities. Nature. 403:853-858.

National Academy of Sciences of the Kyrgyz Republic. 2009. Forest map of the Kyrgyz Republic, scale 1:1500000. Bishkek: Natural Resources Management Rural Economy Local Governance and Civil Society, State Agency for Environmental Protection and Forestry under the National Academy of Sciences of the Kyrgyz Republic, Swiss Cooperation Office in the Kyrgyz Republic.

Newton AC. 2007a. Forest ecology and conservation: a handbook of techniques. Oxford: Oxford University Press.

Newton AC. 2007b. Biodiversity loss and conservation in fragmented forest landscapes. The forests of montane Mexico and temperate South America. Wallingford: CABI.

Newton AC. 2008. Conservation of tree species through sustainable use: how can it be achieved in practice? Oryx. 42:195-205.

Newton AC, Cayuela L, Echeverria C, Armesto JJ, Del Castillo RF, Golicher D, Geneletti D, Gonzalez-Espinosa M, Huth A, Lopez-Barrera F, et al. 2009. Toward integrated analysis of human impacts on forest biodiversity: lessons from Latin America. Ecol Soc. 14(2):2.

Newton AC, Oldfield S. 2008. Red Listing the world's tree species: a review of recent progress. Endang Species Res. 6:137-147.

Olson DM, Dinerstein E, Wikramanayake ED, Burgess ND, Powell GVN, Underwood EC, D’ Amico JA, Itoua I, Strand HE, Morrison JC, et al. 2001. Terrestrial ecoregions of the world: a new map of life on earth. BioScience. 51:933-938.

Reimoser F, Armstrong H, Suchant R. 1999. Measuring forest damage of ungulates: what should be considered. For Ecol Manag. 120:47-58.

Rodrigues ASL, Pilgrim JD, Lamoreux JF, Hoffmann M, Brooks TM. 2006. The value of the IUCN Red List for conservation. Trends Ecol Evol. 21:71-76.

Rooney TP, Waller DM. 2003. Direct and indirect effects of white-tailed deer in forest ecosystems. For Ecol Manag. 181:165-176.

Schmidt M. 2005. Utilisation and management changes in South Kyrgyzstan's mountain forests. J Mt Sci. 2:91-104.

Schmidt K. 2006. NTFPs and poverty alleviation in Kyrgyzstan: potential and critical issues. In: Pfund J-L, Robinson P, editors. Non-timber forest products between poverty alleviation and market forces. Bern: Intercooperation.

Schmidt M. 2012. Changing human-environment interrelationships in Kyrgyzstan's walnut-fruit forests. For Trees Livelihoods. 21:253-266.

Schmidt M, Doerre A. 2011. Changing meanings of Kyrgyzstan's nut forests from colonial to postSoviet times. Area. 43:288-296.

Taylor R. 2009. Community based natural resource management in Zimbabwe: the experience of CAMPFIRE. Biodivers Conserv. 18:2563-2583.

Venglovsky BI. 1998. Potentials and constraints for the development of the walnut-fruit forests of Kyrgyzstan. In: Blaser J, Carter J, Gilmour D, editors. Biodiversity and sustainable use of Kyrgyzstan's walnut-fruit forests. Gland, Bern: IUCN, Intercooperation.

Yamamoto S-I. 2000. Forest gap dynamics and tree regeneration. J For Res. 5:223-229. 